\title{
PENANGGULANGAN TINDAK PIDANA PENCUCIAN UANG DI DALAM KERAHASIAAN BANK
}

\author{
Rr. Ani Wijayati ${ }^{*}$ \\ aniwijayati@yahoo.com
}

Fakultas hukum, Universitas Kristen Indonesia

\begin{abstract}
Bank Secrecy (or Financial Privacy) are rights that must be protected from interference by the State and other parties. Bank Secrecy is the soul of a bangking system which is based on the norms of banking practices, contract-based agreement between the bank and its clients, and the written rules set by the State. However, bank secrecy may become one of the factors that trigger the occurrence of money laundering. The factors behind the occurence of money laundering are closely associated with the power or the legislation, and the banking system of a particular country. In other words, the rampant practice of money laundering in a country is closely related to the political will of its government in combating money laundering through its laws and regulations, especially those in the field of banking.
\end{abstract}

\section{Kata Kunci : Penanggulangan Tindak Pidana Pencucian Uang}

\section{Pendahuluan}

Perkembangan teknologi dan globalisasi di sektor perbankan dewasa ini, banyak bank selalu menjadi kegiatan pencucian uang mengingat sektor inilah yang menawarkan jasa instrumen dalam lalu lintas keuangan yang dapat digunakan untuk menyembunyikan atau menyamarkan asal usul suatu dana. Melalui mekanisme ini hasil kejahatan bergerak dari suatu negara kenegara lain yang belum mempunyai sistem hukum yang cukup kuat untuk menanggulangi kegiatan pencucian uang atau bahkan bergerak ke negara yang menerapkan ketentuan rahasia bank secara sangat ketat. ${ }^{1}$ Ketatnya ketentuan rahasia bank, selain berdampak positif seperti diuraikan diatas, juga dapat berdampak negatif. Apabila ketentuan rahasia bank suatu negara sangat ketat dan ruang lingkupnya relatif cukup luas, maka negara tersebut menjadi tempat yang menarik untuk melakukan pencucian uang hasil kejahatan (money laundering). Ketentuan rahasia bank juga dapat menghambat tugas Dewan Perwakilan Rakyat di dalam melakukan pengawasan terhadap pemerintah dan menimbulkan kesulitan bagi para penegak hukum untuk melakukan tugasnya. Bahkan ada pendapat yang menyatakan bahwa suatu negara modern sulit untuk berjalan dengan baik apabila ketentuan rahasia bank yang terlalu ketat. Dikhawatirkan

\footnotetext{
${ }^{*}$ Dosen Tetap Fakultas Hukum UKI Jakarta

${ }^{1}$ A.S. Mamoedin, Analisis Kejahatan Perbankan, Cetakan Pertama, Jakarta: Rafflesia, 1997. hal. 291
}

dengan rahasia bank yang terlalu ketat ini, pelaku kejahatan akan mudah bersembunyi dan pungutan pajak tidak akan berhasil dengan baik. $^{2}$

Pasal 1 angka 28 UU RI No. 10 tahun 1998 tentang Perbankan merumuskan rahasia bank adalah segala sesuatu yang berhubungan dengan keterangan mengenai penyimpanan dan simpanannya. Bank wajib merahasiakan keterangan mengenai nasabah penyimpanan dan simpanannya, namun ketentuan tersebut ada pengecualiannya. Kewajiban merahasiakan itu dikecualikan untuk kepentingan perpajakan, penagihan piutang bank terutama piutang bank milik negara, kepentingan peradilan perkara pidana, dalam hal sengketa perdata antara bank dan nasabah di pengadilan, informasi antara bank, kepentingan ahli waris dan adanya persetujuan atau kuasa tertulis dari nasabah. ${ }^{3}$

Ketentuan pengecualian mengenai rahasia bank juga diatur dalam pasal 7 UU RI No. 8 tahun 2010 tentang pencegahan dan pemberantasan tindak pidana pencucian uang, ditentukan untuk kepentingan pemeriksaan dalam perkara tindak pidana pencucian uang, penyidik penuntut umum atau hakim berwenang meminta pihak pelapor untuk memberikan keterangan secara tertulis mengenai harta keka-

\footnotetext{
${ }^{2}$ OECD, Internasional Tax Avoidance and Evasion, Paris, 1985, hal.108

${ }^{3}$ Pasal 41 sampai pasal 44A UU No. 7 tahun 1992 tentang Perbankan sebagaimana telah diubah dengan UU No. 10 tahun 1998
} 
yaan dan dalam hal ini tidak berlaku ketentuan peraturan perundang-undangan yang mengatur rahasia bank dan kerahasiaan transaksi keuangan lainnya.

\section{Permasalahan}

1. Apakah ketentuan rahasia bank yang ada saat ini sudah responsif terhadap penanggulangan tindak pidana pencucian uang?

2. Bagaimanakah upaya Perbankan dalam penanggulangan tindak pidana pencucian uang?

\section{Tujuan Penulisan}

1. Untuk mengetahui ketentuan rahasia bank dapat menanggulangi tindak pidana pencucian uang.

2. Untuk mengetahui upaya yang dilakukan perbankan dalam penanggulangan tindak pidana pencucian uang.

\section{Rahasia Bank}

Menurut Pasal 2 angka 28 UU RI No. 10 tahun 1998 tentang Perbankan yang dimaksud dengan rahasia bank adalah segala sesuatu yang berhubungan dengan keterangan mengenai nasabah penyimpanan dan simpanananya.

Dari pengertian di atas, maka unsur-unsur dari rahasia bank, yaitu :

1. Rahasia bank tersebut berhubungan dengan keterangan mengenai nasabah penyimpanan dan simpananya. Ini berarti tidak termasuk mengenai "nasabah debitur" dan "pinjaman".

2. Hal tersebut wajib dirahasiakan oleh bank, kecuali termasuk ke dalam kategori perkecualian berdasarkan prosedur dan peraturan perundang-undangan yang berlaku.

3. Pihak yang dilarang membuka rekening bank adalah pihak bank itu sendiri dan atau pihak terapiliasi, yang dimaksud pihak terapiliasi adalah sebagai berikut :

a. Anggota dewan komisaris, pengurus direksi atau kuasanya, pejabat atau karyawan bank yang bersangkutan.

b. Anggota pengurus, pengawas, pengelola atau kuasanya, pejabat atau karyawan bank khusus bagi bank berbentuk Badan Hukum Koperasi sesuai dengan peraturan perundang-undangan yang berlaku. c. Pihak yang memberikan jasanya kepada bank antara lain akuntan publik, partai, konsultan hukum dan konsultan lainnya.

d. Pihak yang menurut penilaian Bank Indonesia turut serta mempengaruhi pengelolaan bank, tetapi tidak terbatas pada pemegang saham dan keluarganya, keluarga komisaris, keluarga pengawas, keluarga direksi dan keluarga pengurus.

Menurut Sutan Remy Syahdeini tentang pencucian uang ialah rangkaian kegiatan yang merupakan proses yang dilakukan oleh seseorang atau organisasi terhadap uang haram, yaitu uang yang berasal dari kejahatan dengan maksud untuk menyembunyikan atau menyamarkan asal usul uang tersebut dari pemerintah atau otoritas yang berwenang melakukan penindakan terhadap tindak pidana dengan cara terutama memasukkan uang tersebut ke dalam sistem keuangan (financial system), sehingga uang tersebut kemudian dapat dikeluarkan dari sistem keuangan itu sebagai uang halal. ${ }^{4}$

Sedangkan Pasal 1 angka 1 UU RI No. 8 tahun 2010 tentang Pencegahan dan Pemberantasan Tindak Pidana Pencucian Uang, Pencucian Uang adalah segala perbuatan yang memenuhi unsur-unsur tindak pidana sesuai dengan ketentuan undang-undang ini. Tindak pidana pencucian uang menurut undang-undang ini adalah :

a. Setiap orang yang menempatkan, mentransfer, mengalihkan, membelanjakan, membayarkan, menghibahkan, menitipkan, membawa keluar negeri, mengubah bentuk, menukarkan dengan mata uang atau surat berharga atau perbuatan lain atas harta kekayaan yang diketahuinya atau patut diduganya merupakan hasil tindak pidana sebagaimana dimaksud dalam pasal 2 ayat (1) dengan tujuan menyembunyikan atau menyamarkan asal usul harta kekayaan dipidana karena tindak pidana pencucian uang dengan pidana penjara paling lama 20

\footnotetext{
$\overline{4}$ Sutan Remy Syahdieni, Pencucian Uang : Pengertian, Sejarah, Faktor-faktor Penyebab dan Dampaknya bagi Masyarakat, Jurnal Hukum Bisnis, Volume 22 Nomor 3 tahun 2003, hal.6
} 
(dua puluh) tahun dan denda paling banyak sepuluh milyar rupiah. ${ }^{5}$

b. Setiap orang yang menyembunyikan atau menyamarkan asal usul sumber, lokasi, peruntukan, pengalihan hak-hak atau kepemilikan yang sebenarnya atas harta kekayaan yang diketahuinya atau patut diduganya merupakan hasil tindak pidana sebagaimana dimaksud dalam pasal 2 ayat (1) dipidana karena tindak pencucian uang dengan pidana penjara paling lama 20 (dua puluh) tahun dan denda paling banyak lima milyar rupiah. ${ }^{6}$

c. Setiap orang yang menerima atau menguasai penempatan, pentransferan, pembayaran, hibah, sumbangan, penitipan, penukaran, atau menggunakan harta kekayaan yang diketahuinya atau patut diduganya merupakan hasil tindak pidana sebagaimana dimaksud dalam pasal 2 ayat (1) dipidana sebagaimana dimaksud dalam pasal 1 ayat (1) dipidana dengan pidana penjara paling lama lima tahun dan denda paling banyak satu milyar rupiah. ${ }^{7}$

Pengertian pencucian uang juga termuat dalam The United Nations Convention against Illict Traffice in Narcotic Drugs and Pyshotropic Substances of 1988 (konvensi PBB) yang disahkan pada tanggal 19 Desember 1988 di Vienna yang diratifikasi di Indonesia dengan undang-undang Nomor 7 tahun 1997 pada tanggal 31 Desember 1997 secara lengkap pengertian money laundering adalah :

The conversion or transfer of property, knowing that such property is derived from any serious (indictable) offence or offences, or from act of participation in such offence of offences, for the purpose of concealing or disquising the illict of the property or of assisting any person who is involved in the comission of such an offence of offences to evade the legal consequences of his action, or the concealment or disquise of the arme nature,

\footnotetext{
${ }^{5}$ Pasal 3 UU No. 8 tahun 2010 tentang Pencegahan dan Pemberantasan Tindak Pidana Pencucian Uang.

${ }^{6}$ Pasal 4 UU No. 8 tahun 2010 tentang Pencegahan dan Pemberantasan Tindak Pidana Pencucian Uang.

${ }^{7}$ Pasal 5 (1) UU RI No. 8 Tahun 2010 tentang Pencegahan dan Pemberantasan Tindak Pidana Pencucian Uang.
}

sovice, pocation, disposition, movement, right with respect to or ownership of property, knowing that such property is deruved from a serios (indictable) offence or offences or from an act of participation in such an offence on offences.

Secara umum pencucian uang merupakan metode untuk menyembunyikan, memindahkan dan menggunakan hasil dari suatu tindak pidana, kegiatan organisasi kejahatan, kejahatan ekonomi, korupsi, perdagangan narkotika dan kegiatan-kegiatan lainnya yang merupakan diskuitas kejahatan.

\section{Obyek Pencucian Uang dan Tindak Pi-dana Asal (Predicate Crime)}

Menurut Surah N. Welling, money laundering dimulai dengan adanya "uang haram" atau "uang kotor". Dalam UU TPPU yang dimaksud dengan uang haram adalah uang hasil kejahatan. Kejahatan yang dimaksud dalam undang-undang adalah yang disebut tindak pidana asal (predicate crime), UU TPPU menentukan sebagai predicate crime adalah korupsi, penyuapan, narkotika, penyelundupan tenaga kerja, penyelundupan migran, di bidang perbankan, dibidang pasar modal, di-bidang perasuransian, kepabrikan, cukai, perdagangan orang, perdagangan senjata gelap, pemalsuan uang, perjudian, prostisusi di bidang perpajakan, dibidang kehutanan, di bidang lingkungan hidup, dibidang kelautan dan perikanan atau tindak pidana lainnya yang diancam dengan pidana penjara 4 (empat) tahun atau lebih, yang dilakukan diwilayah Negara Kesatuan Republik Indonesia atau diluar wilayah Negara Kesatuan Republik Indonesia dan tindak pidana tersebut juga merupakan tindak pidana menurut Hukum Indonesia.

Sedangkan transaksi keuangan yang mencurigakan antara lain : 8

a. Transaski keuangan yang menyimpang dari profil, karakteristik atau kebiasaan pola transaksi dari pengguna jasa.

b. Transaksi keuangan oleh pengguna jasa yang patut diduga dilakukan dengan tujuan untuk menghindari pelaporan transaksi yang bersangkutan yang wajib dilakukan

\footnotetext{
${ }^{8}$ Pasal 1 angka 5 UU RI No. 8 Tahun 2010 tentang Pencegahan dan Pemberantasan Tindak Pidana Pencucian Uang.
} 
oleh pihak pelapor sesuai dengan ketentuan undang-undang ini.

c. Transaski keuangan yang dilakukan atau batal dilakukan dengan menggunakan harta kekayaan yang diduga berasal dari hasil tindak pidana.

d. Transaski keuangan yang diminta oleh $\mathrm{Pu}$ sat Pelaporan dan Analisis Transaksi Keuangan (PPATK) untuk dilaporkan oleh pihak pelapor karena melibatkan harta kekayaan yang diduga berasal dari hasil tindak pidana.

Kemungkinan lain, orang dianggap melakukan pencucian uang adalah orang melakukan transaksi keuangan tunai dalam jumlah paling sedikit lima ratus juta rupiah atau dengan mata uang asing yang dinilainya setara yang dilakukan baik dalam satu kali hari kerja dan atau transaksi keuangan transfer dana dari dan ke luar negeri.

Adapun yang diwajibkan untuk melapor bila terjadi transaksi keuangan yang harus dilaporkan adalah penyedia jasa keuangan dan penyedia barang dan atau jasa lain. Kewajiban pelaporan ini bila tidak dilakukan membawa konsekuensi sanksi administratif.

Salah satu faktor untuk dapat memelihara dan meningkatkan kadar kepercayaan masyarakat terhadap suatu bank pada khususnya dan perbankan pada umumnya ialah kepatuhan bank terhadap kewajiban rahasia bank. Adanya ketentuan mengenai rahasia bank ini menimbulkan kesan bagi masyarakat, bahwa bank sengaja untuk menyembunyikan keadaan keuangan yang tidak sehat dari nasabah, baik orang perorangan atau perusahaan yang menjadi sorotan masyarakat. Selama ini timbul kesan bahwa dunia perbankan bersembunyi dibalik ketentuan rahasia bank untuk melindungi kepentingan nasabahnya yang belum tentu benar. Tetapi, apabila bank sungguh-sungguh melindungi kepentingan nasabahnya yang jujur dan bersih, maka hal itu merupakan suatu keharusan dan kepatutan.

Filosofi adanya kewajiban bank memegang rahasia keuangan nasabah atau perlindungan atas kerahasiaan keuangan nasabah didasari dari beberapa alasan yaitu $:^{9}$

\footnotetext{
${ }^{9}$ Bambang Setijopmodjo, Rahasia Bank, Bahan Program Pelatihan Calon Jurist Angkatan VI Bank Negara Indonesia (Persero), Jakarta, 1995, hal. 5
}

a. Hak setiap orang atau badan untuk tidak dicampuri atas masa lalu yang bersifat pribadi (personal privacy);

b. Hak yang timbul dari hubungan perikatan antara bank dan nasabahnya. Dalam kaitan ini bank wajib melindungi kepentingan nasabah.

c. Atas dasar ketentuan perundang-undangan yang berlaku yaitu UU RI No. 7 tahun 1992 sebagaimana telah diubah dengan UU RI No. 10 tahun 1998 yang menegaskan bahwa berdasarkan fungsi utama bank dalam menghimpun dana dari masyarakat. Dengan demikian pengetahuan tentang keadaan keuangan nasabah tidak disalahgunakan dan wajib dijaga kerahasiaannya oleh setiap orang.

d. Kebiasaan dan kelaziman dalam dunia perbankan.

e. Karakteristik kegiatan usaha bank.

Timbulnya pemeliharaan untuk perlunya merahasiakan keadaan keuangan nasabah bank, sehingga melahirkan hukum mengenai kewajiban rahasia bank, semula bertujuan untuk melindungi kepentingan nasabah secra individual. Namun, perkembangan sehubungan dengan keadaan positif dalam negeri, keadaan sosial terutama yang menyangkut timbulnya kejahatan-kejahatan di bidang money laundering dan kebutuhan akan adanya stabilitas ekonomi terutama stabilitas moneter, telah menimbulkan kebutuhan akan perlunya pelanggaran terhadap kewajiban rahasia bank yang mutlak itu. Artinya, apabila kepentingan negara, bangsa dan masyarakat umum harus didahulukan daripada kepentingan nasabah secara pribadi, maka kewajiban bank untuk melindungi kepentingan nasabah secara individual itu (dalam arti boleh mengungkapkan keadaan keuangan nasabah) harus dapat dikesampingkan. Contoh yang konkret mengenai hal ini di dalam berkaitan dengan kepentingan negara untuk menghitung pajak nasabah yang bersangkutan, penindakan korupsi dan pemberantasan money laundering.

Merupakan hal yang kontradiktif bahwa dalam hal-hal tertentu justru demi kepentingan negara, bangsa dan masyarakat umum, dikehendaki agar kewajiban rahasia bank diperketat. Kepentingan negara yang dimaksud adalah pengarahan dana perbankan untuk keperluan 
pembanding. Kepentingan negara, bangsa dan masyarakat umum itu dilandasi oleh alasan bahwa dijunjung tinggi dan dipegang teguhnya kewajiban rahasia bank merupakan faktor terpenting bagi keberhasilan bank dalam upaya bank itu mengalihkan tabungan masyarakat, dan terganggunya stabilitas moneter antara lain dapat diakibatkan oleh runtuhnya kepercayaan masyarakat terhadap perbankan karena terlalu longgarnya rahasia bank.

Bagi Indonesia kerahasiaan bank bukan sesuatu yang mutlak atau "harga mati" melainkan "dalam hal tertentu", bank masih dimungkinkan menginformasikan keterangan dan keadaan keuangan nasabahnya kepada pihak lain asalkan hal itu dilakukan demi kepentingan umum atau masyarakat bank. ${ }^{10}$

Kaitan antara rahasia bank dan peradilan yang terdapat dalam pasal 42 dan pasal 43 mengandung kelemahan. Menurut Pasal 42 UU RI No. 7 tahun 1992 sebagaimana telah diubah dengan UU RI No. 10 tahun 1998 : polisi, jaksa dan hakim yang ingin memperoleh dari Gubernur Bank Indonesia, masing-masing melalui kepala kepolisian, jaksa agung dan ketua mahkamah agung RI. Sedangkan menurut $\mathrm{Pa}$ sal 43 UU Perbankan yang menentukan bahwa dalam perkara perdata antara bank dan nasabahnya, direksi bank yang bersangkutan dapat menginformasikan kepada pengadilan tentang keadaan keuangan nasabah yang bersangkutan dan memberikan keterangan lain yang relevan dengan perkara tersebut.

Dalam hal ini bank memberikan keterangan dalam kapasitas sebagai penggugat atau tergugat. Bagaimana apabila yang berperkara bukanlah bank dan nasabahnya, apakah pengadilan boleh meminta keterangan dari bank. Menurut doktrin bank dapat saja memberikan keterangan di depan pengadilan walaupun

\footnotetext{
${ }^{10}$ Terdapat 2 (dua) teori berkenaan kerahasiaan bank yaitu teori rahasia bank yang bersifat mutlak (absolutly theory) dan teori rahasia bank yang bersifat relatif atau ; Indonesia menganut teori rahasia yang bersifat relatif. The Fourty Recommendation ini dikeluarkan oleh FATF dan didukung oleh badan-badan kerjasama internasional lainnya yang bertujuan memberantas pencucian uang, antara lain APG, di mana Indonesia sebagai salah satu anggotanya.Yang dimaksud lembaga keuangan adalah baik bank-bank, maupun lembaga keuangan nonbank, antara lain lembaga pembiayaan, perusahaan asuransi, perusahaan sekuritas maupun perusahaan penukar uang.
}

bank tidak sedang berperkara perdata dengan nasabahnya dengan syarat.

a. Bank memberikan keterangan untuk mempertaruhkan haknya di pengadilan.

b. Bank memberikan keterangan atas permintaan pengadilan atau untuk memenuhi ketentuan hukum acara di pengadilan. Hal ini merupakan kewajiban bagi setiap warganya dalam rangka pencegahan hukum.

\section{Upaya-upaya Pemberantasan Kejahatan Pencucian Uang (Money laundering)}

Seberapa jauh bank dapat berperan dalam pencegahan dan pemberantasan tindakan pencucian uang dapat dilihat dari The Fourty Reccomendation $^{11}$ (empat puluh rekomendasi) dalam rangka memerangi praktik-praktik pencucian uang. Di antara empat puluh rekomendasi tersebut terdapat beberapa rekomendasi yang secara khusus menyangkut lembaga-lembaga keuangan dan secara khusus menyangkut badan-badan otoritas yang bertanggung jawab melakukan pengaturan dan pengawasan lembaga-lembaga keuangan. ${ }^{12}$ Rekomendasi tersebut antara lain:

1. Bank dan lembaga keuangan non bank diminta untuk tidak membuka rekening tanpa nama atau yang anonim (anonymous accounts), atau rekening yang jelas-jelas menggunakan nama fiktif. Larangan ini harus dituangkan dalam bentuk peraturan perundang-undangan.

2. Lembaga keuangan diharapkan mengupayakan informasi mengenai kebenaran identitas dari orang-orang yang atas namanya rekening dibuka atau atas namanya suatu transaksi dilakukan.

3. Lembaga keuangan diminta untuk memelihara sekurang-kurangnya lima tahun catatan mengenai transaksi yang dilakukan oleh lembaga keuangan dengan nasabah,

\footnotetext{
11 The Fourty Recomendation ini dikeluarkan oleh FATF (Finacial Act Tax Force) dan didukung oleh Badan-Badan Kerjasama Internasional lainnya yang bertujuan memberantas pencucian uang, antara lain APG, dimana Indonesia sebagai salah satu anggotanya.

${ }^{12}$ Yang dimaksud lembaga keuangan adalah baik bankbank, maupun lembaga keuangan non bank, antara lain lembaga pembiayaan, perusahaan asuransi, perusahaan sekuritas maupun penukar uang, serta kantor pos.
} 
baik transaksi dalam negeri maupun internasional.

4. Setiap negara termasuk lembaga keuangannya diminta untuk memberikan perhatian terhadap ancaman-ancaman pencucian uang sehubungan dengan perkembangan teknologi yang memungkinkan dilakukan pencucian uang.

5. Setiap negara diminta memberikan perhatian terhadap transaksi dalam jumlah yang besar dan semua transaksi yang tidak lazim.

6. Meminta agar apabila lembaga keuangan menaruh curiga bahwa dana yang disetorkan nasabah berasal dari kegiatan kejahatan, maka lembaga keuangan tersebut diharuskan untuk secepatnya malaporkan kecurigaan tersebut kepada otoritas yang berwenang.

7. Lembaga keuangan, para anggota direksinya, para pejabatnya, dan para pegawainya diminta untuk tidak atau apabila tidak memadai, untuk tidak diizinkan memberikan peringatan kepada para nasabah bahwa informasi mengenai diri nasabah yang bersangkutan sedang dilaporkan kepada otoritas yang berwenang.

8. Lembaga-lembaga keuangan diminta untuk menyusun program yang menyangkut pemberantasan pencucian uang.

\section{Asas-asas Perbankan dan Upaya Menganti- sipasi Kejahatan Pencucian Uang (Money laundering)}

Dalam hukum perbankan, dikenal beberapa asas, yaitu asas kepercayaan (fiduciary relation), asas kehati-hatian (prudential principle), asas mengenal nasabah (know your customer principle), dan asas kerahasiaan (secrecy principle). Asas Hukum ada yang tidak dituangkan dalam bentuk peraturan yang konkret dalam pasal-pasal, ada pula yang dituangkan dalam ketentuan-ketentuan konkret.

\section{a. Asas Kepercayaan}

Asas kepercayaan adalah suatu asas yang menyatakan bahwa usaha bank dilandasi oleh hubungan kepercayaan antara bank dan nasabahnya. ${ }^{13}$ Bank berusaha da-

\footnotetext{
${ }^{13}$ Rahmadi Usman, yang dikutip Johanes Ibrahim, artikel pada Jurnal Hukum LITIGASI, Fakultas Hukum
}

ri dana masyarakat yang disimpan berdasarkan kepercayaan sehingga setiap bank perlu untuk menjaga kesehatan banknya dengan tetap memelihara dan mempertahankan kepercayaan masyarakat. Asas kepercayaan diatur dalam pasal 29 ayat (4) UU RI No. 10 Tahun 1998 tentang Perubahan Atas UU RI No. 7 Tahun 1992 tentang Perbankan.

\section{b. Asas Kehati-hatian}

Asas kehati-hatian adalah suatu asas yang menyatakan bahwa bank dalam menjalankan dan kegiatan usahanya wajib menerapkan prinsip kehati-hatian dalam rangka melindungi dana masyarakat yang dipercayakan pada bank. Tujuan dilakukannya prinsip ini agar bank selalu dalam keadaan sehat, menjalankan usahanya dengan baik dan benar dengan mematuhi ketentuan-ketentuan dan norma-norma hukum yang berlaku dalam dunia perbankan. Hubungan asas kehati-hatian ini dengan tindakan pencucian uang, yakni asas ini merupakan peringatan (warning) pada bank agar berhati-hati dalam melakukan transaksi supaya tidak melakukan transaksi yang dilarang oleh peraturan. Asas kehatihatian diatur dalam Pasal 2 dan Pasal 29 ayat (2) UU RI No. 10 Tahun 1998.

\section{c. Asas Kerahasiaan}

Ketentuan tentang rahasia bank diatur dalam Bab VII dan Bab VIII Pasal 40 sampai dengan Pasal 47 dan Pasal 47 A UU RI No. 10 Tahun 1998. Menurut Pasal 40, bank wajib merahasiakan keterangan mengenai nasabah penyimpan dan simpanannya. Namun ketentuan Pasal 40 tersebut kewajiban merahasiakan itu bukan tanpa pengecualian. Kewajiban merahasiakan itu dikecualikan dalam hal-hal untuk kepentingan pajak, untuk penyelesaian piutang bank yang sudah diserahkan kepada Badan Urusan Piutang dan Lelang/Panitia Urusan Piutang Negara (BUPLN/PUPN), untuk kepentingan pengadilan dalam perkara pidana, dalam perkara perdata antar bank dengan nasabahnya, dalam rangka tukar menukar informasi antar bank.

UNPAS, Bandung, Volume 5 No. 2, Juni 2004, hal. 171-173. 
Pembuat UU TPPU memberikan fasilitas khusus kepada penyidik, penuntut umum dan hakim untuk dikecualikan dari ketentuan rahasia bank. Pengecualian tersebut ditentukan dalam Pasal 33 UU TPPU. Dengan demikian, berlakunya UU TPPU, pengecualian terhadap ketentuan rahasia bank yang semula hanya lima, yaitu yang ditentukan dalam UU Perbankan, sekarang menjadi tujuh, yaitu dengan tambahan dua dari UU TPPU.

\section{d. Asas Mengenal Nasabah}

Menurut peraturan Bank Indonesia No. 3/10/PBI/2001 tentang Penerapan Prinsip Mengenal Nasbah, Prinsip Mengenal Nasabah adalah: "Prinsip yang diterapkan oleh bank untuk mengenal dan mengetahui identitas nasabah, memantau kegiatan transaksi nasabah termasuk melaporkan setiap transaksi yang mencurigakan. Prinsip ini merupakan sarana yang paling efektif bagi perbankan untuk menanggulangi kegiatan pencucian uang yang banyak dilakukan melalui perbankan. ${ }^{14}$

Asas mengenal nasabah memiliki urgensi yang mendasar dalam transaksi transaksi perbankan yang sangat berkaitan dengan banking di mana transaksi ini memberikan akses yang cepat bagi nasabah untuk melakukan tindak pidana pencucian uang.

\section{Kesimpulan}

1. Ruang lingkup rahasia bank di Indonesia terus mengalami perubahan dari waktu ke waktu. Pada pengaturan awal rahasia bank hanya meliputi nasabah penyimpanan dana dan nasabah peminjaman dana, kemudian meluas meliputi seluruh nasabah penyimpanan dana, peminjaman dan nasabah pengguna jasa bank. Sekarang ruang lingkup obyek rahasia bank hanya sebatas meliputi penyimpanan dana dan simpananannya. Indonesia menganut ketentuan rahasia bank yang tidak bersifat mutlak, sehingga apabila ada kepentingan umum yang lebih besar, maka ketentuan rahasia bank tidak

\footnotetext{
${ }^{14}$ Yunus Husein, Penerapan Prinsip Mengenal Nasabah oleh Bank dalam Rangka Penanggula-ngan Money laundering, artikel pada Jurnal Hukum Bisnis, Volume 16 Tahun 2001, hal. 31.
}

dapat dipertahankan. Hal ini sehubungan dengan keadaan politik dalam negeri, keadaan sosial, terutama yang menyangkut timbulnya kejahatan di bidang pencucian uang.

2. Perbankan adalah alat utama yang paling menarik digunakan dalam pencucian uang mengingat perbankan merupakan lembaga keuangan yang menerapkan ketentuan rahasia bank yang dapat dijadikan "tameng" untuk bersembunyi bagi pelaku tindak pidana pencucian uang. Upaya bank untuk mencegah tindak pidana pencucian uang dalam rahasia bank yaitu dengan menerapkan asas-asas perbankan dan pelaksanaan rekomendasi dari the fourty reccomendation dalam rangka memerangi praktek pencucian uang.

\section{Saran}

1. Untuk mempermudah proses penyusutan perkara pidana berkaitan dengan tindak pidana pencucian uang sebaiknya dimungkinkan bagi bank untuk menerima kuasa atau permintaan tertulis dari nasabah guna memberikan keterangan kepada petugas penyidik, penuntut umum atau pengadilan.

2. Ketentuan rahasia bank yang berkaitan dengan penyidikan dapat disempurnakan, misalnya dengan mempersingkat waktu pemberian izin membuka rahasia yang diberikan gubernur bank Indonesia. 


\section{Daftar Pustaka}

\section{Buku :}

A.S. Mamoedin, Analisis Kejahatan Perbankan, Cetakan Pertama, Jakarta: Rafflesia, 1997 Bambang Setijopmodjo, Rahasia Bank, Bahan Program Pelatihan Calon Jurist Angkatan VI Bank

Negara Indonesia (Persero), Jakarta, 1995

Sutan Remy Syahdieni, Pencucian Uang : Pengertian, Sejarah, Faktor-faktor Penyebab dan Dampaknya bagi Masyarakat, Jurnal Hukum Bisnis, Volume 22 Nomor 3 tahun 2003

Rahmadi Usman, yang dikutip Johanes Ibrahim, artikel pada Jurnal Hukum LITIGASI, Fakultas Hukum UNPAS, Bandung, Volume 5 No. 2, Juni 2004

Yunus Husein, Penerapan Prinsip Mengenal Nasabah oleh Bank dalam Rangka

Penanggulangan Money laundering, artikel pada Jurnal Hukum Bisnis, Volume 16 Tahun 2001

\section{Undang-Undang:}

UU RI No. 7 tahun 1992 tentang Perbankan sebagaimana telah diubah dengan UU RI No. 10 tahun 1998 tentang Perbankan

UU RI No. 8 tahun 2010 tentang Pencegahan dan Pemberantasan Tindak Pidana Pencucian Uang. 